\title{
Brain Injury in COVID-19 is Associated with Autoinflammation and Autoimmunity
}

Needham EJ, ${ }^{1,2}$ Ren AL, ${ }^{2}$ Digby RJ, ${ }^{2}$ Outtrim JG, ${ }^{2}$ Chatfield DA, ${ }^{2}$ Manktelow AE, ${ }^{2}$ Newcombe VFJ, ${ }^{2}$ Doffinger $\mathrm{R},{ }^{3}$ Barcenas-Morales $\mathrm{G},{ }^{3}$ Fonseca $\mathrm{C},{ }^{4}$ Taussig MJ, ${ }^{4}$ Burnstein RM, ${ }^{2}$ Dunai $\mathrm{C},{ }^{5}$ Sithole $\mathrm{N}, 6,7,8$

Ashton NJ, ${ }^{9}$ Zetterberg $\mathrm{H},{ }^{9-13}$ Gisslen $\mathrm{M},{ }^{14,15}$ Edén A, ${ }^{14,15}$ Marklund E, ${ }^{14,15}$ Griffiths MJ, ${ }^{16}$ Cavanagh J, ${ }^{17}$ Breen $\mathrm{G}_{1}{ }^{18}$ Irani SR, ${ }^{19,20}$ Elmer A, ${ }^{21}$ Kingston N, ${ }^{22,23}$ Bradley JR, ${ }^{7,22}$ Taams LS, ${ }^{24}$ Michael BD, ${ }^{5}$ Bullmore $\mathrm{ET}^{25}{ }^{25}$ Smith KGC, ${ }^{7,8}$ Lyons PA, ${ }^{7,8}$ Coles AJC, ${ }^{1}$ Menon DK ${ }^{2}$; and the Cambridge NeuroCOVID Group, ${ }^{a}$ the NIHR COVID-19 BioResource, ${ }^{b}$ and Cambridge NIHR Clinical Research Facility ${ }^{c}$

aCambridge NeuroCOVID Group: Anwar F, Allinson K, Bhatti J, Bullmore ET, Chatfield DA, Christmas D, Coles AJ, Coles JP, Correia M, Das T, Fletcher PC, Jubb AW, Lupson VC, Manktelow AE, Menon DK, Michell A, Needham EJ, Newcombe VFJ, Outtrim JG, Pointon L, Rodgers CT, Rowe JB, Rua C, Sithole N, Spindler LRB, Stamatakis EA, Taylor J, Valerio F, Widmer B, Williams GB.

${ }^{b}$ NIHR COVID-19 BioResource ${ }^{22}$ : Kingston N, Graves B, Le Gresley E, Caputo D, Stark H, Townsend P, Stirrups KE, Chinnery PF, Bradley JR.

'NIHR Cambridge Clinical Research Facility: Saunders C, Elmer A

1. Department of Clinical Neurosciences, University of Cambridge, UK.

2. Division of Anaesthesia, Department of Medicine, University of Cambridge, UK.

3. Department of Clinical Biochemistry and Immunology, Addenbrooke's Hospital, Cambridge, UK.

4. Cambridge Protein Arrays Ltd, Babraham Research Campus, Cambridge, UK.

5. Clinical Infection Microbiology and Neuroimmunology, Institute of Infection, Veterinary and Ecological Science, Liverpool, UK.

6. Department of Infectious Diseases, Cambridge University NHS Hospitals Foundation Trust, Cambridge, UK.

7. Department of Medicine, University of Cambridge, Addenbrooke's Hospital, Cambridge, UK.

8. Cambridge Institute of Therapeutic Immunology and Infectious Disease, Jeffrey Cheah Biomedical Centre, University of Cambridge, Cambridge, UK

9. Department of Psychiatry and Neurochemistry, Institute of Neuroscience \& Physiology, the Sahlgrenska Academy at the University of Gothenburg, Mölndal, Sweden.

10. Clinical Neurochemistry Laboratory, Sahlgrenska University Hospital, Mölndal, Sweden.

11. Department of Neurodegenerative Disease, UCL Institute of Neurology, Queen Square, London, UK.

12. UK Dementia Research Institute at UCL, London, UK.

13. Hong Kong Center for Neurodegenerative Diseases, Hong Kong, China.

14. Department of Infectious Diseases, Institute of Biomedicine, the Sahlgrenska Academy at the University of Gothenburg, Gothenburg, Sweden.

15. Region Västra Götaland, Sahlgrenska University Hospital, Department of Infectious Diseases, Gothenburg, Sweden.

16. Institute of Infection, Veterinary \& Ecological Sciences, University of Liverpool, Liverpool, UK.

17. Centre for Immunobiology, Institute of Infection, Immunity and Inflammation, College of Medical, Veterinary and Life Sciences, University of Glasgow, Glasgow, UK.

18. Department of Social Genetic and Developmental Psychiatry, King's College London, London, UK.

19. Oxford Autoimmune Neurology Group, Nuffield Department of Clinical Neurosciences, University of Oxford, Oxford, UK.

20. Department of Neurology, Oxford University Hospitals NHS Foundation Trust, Oxford, UK. NOT21:This Cambridge Clinical Research Centre, NIHR Clinical Research Facility, Cambridge University Hospitals NHS Foundation Trust, Addenbrooke's Hospital, Cambridge, UK. 
medRxiv preprint doi: https://doi.org/10.1101/2021.12.03.21266112; this version posted December 5, 2021. The copyright holder for this preprint (which was not certified by peer review) is the author/funder, who has granted medRxiv a license to display the preprint in It is made available under a CC-BY-ND 4.0 International license .

22. NIHR BioResource, Cambridge University Hospitals NHS Foundation, Cambridge Biomedical Campus, Cambridge, UK.

23. Department of Haematology, School of Clinical Medicine, University of Cambridge, Cambridge Biomedical Campus, Cambridge, UK

24. Centre for Inflammation Biology and Cancer Immunology (CIBCI) \& Dept Inflammation Biology, School of Immunology \& Microbial Sciences, King's College London, Guy's Campus, London, UK.

25. Department of Psychiatry, University of Cambridge, Herchel Smith Building for Brain and Mind Sciences, Cambridge Biomedical Campus, Cambridge, UK.

\section{Abstract}

COVID-19 has been associated with many neurological complications including stroke, delirium and encephalitis. Furthermore, many individuals experience a protracted post-viral syndrome which is dominated by neuropsychiatric symptoms, and is seemingly unrelated to COVID-19 severity. The true frequency and underlying mechanisms of neurological injury are unknown, but exaggerated host inflammatory responses appear to be a key driver of severe COVID-19 more broadly.

We sought to investigate the dynamics of, and relationship between, serum markers of brain injury (neurofilament light [NfL], Glial Fibrillary Acidic Protein [GFAP] and total Tau) and markers of dysregulated host response including measures of autoinflammation (proinflammatory cytokines) and autoimmunity. Brain injury biomarkers were measured using the Quanterix Simoa HDx platform, cytokine profiling by Luminex (R\&D) and autoantibodies by a custom protein microarray.

During hospitalisation, patients with COVID-19 demonstrated elevations of NfL and GFAP in a severity-dependant manner, and there was evidence of ongoing active brain injury at follow-up 4 months later. Raised NfL and GFAP were associated with both elevations of pro-inflammatory cytokines and the presence of autoantibodies; autoantibodies were commonly seen against lung surfactant proteins as well as brain proteins such as myelin associated glycoprotein, but reactivity was seen to a large number of different antigens.

Furthermore, a distinct process characterised by elevation of serum total Tau was seen in patients at follow-up, which appeared to be independent of initial disease severity and was not associated with dysregulated immune responses in the same manner as NfL and GFAP. 
medRxiv preprint doi: https://doi.org/10.1101/2021.12.03.21266112; this version posted December 5, 2021. The copyright holder for this preprint (which was not certified by peer review) is the author/funder, who has granted medRxiv a license to display the preprint in It is made available under a CC-BY-ND 4.0 International license .

\section{Introduction}

COVID-19 has been associated with several neurological complications including stroke and immunemediated disorders such as Guillain-Barré syndrome and autoimmune encephalitis. ${ }^{1}$ Furthermore, up to a third of infected individuals experience a protracted post-viral syndrome following COVID-19 which is potentially of CNS origin given the dominance of neuropsychiatric symptoms such as fatigue and subjective cognitive difficulties.$^{2-4}$ While the occurrence of physical brain injury is overt in some COVID-19-associated neurological syndromes such as stroke and encephalitis, a number of studies have suggested that brain injury can occur in the context of COVID-19 even in the absence of a clear concomitant neurological diagnosis. However, the mechanism that might drive this process requires further attention. ${ }^{5-15}$ In COVID-19 disease, exaggerated host inflammatory responses appear to be a key driver of severe disease, and the most effective established therapies for systemic COVID-19 aim to attenuate this response. ${ }^{16,17}$ Initial attention focused on the innate immune system as a key driver, and emerging evidence also suggests a significant role for dysregulated adaptive immune responses. ${ }^{18}$ This combined maladaptive response is reminiscent of that seen in a spectrum of immune-mediated diseases - which extend from autoinflammatory to autoimmune in nature described in non-COVID-19 settings. ${ }^{19}$

Here, we seek to investigate markers of a dysregulated immune host response, including surrogates of autoinflammation (proinflammatory cytokines) and autoimmunity (autoantibodies), and how they correlate with biomarkers of brain injury.

\section{Methods}

\section{Study populations}

Patients admitted to Cambridge University Hospital, UK with PCR-proven COVID-19 were identified between March 2020 and March 2021. Providing research personnel were available, all patients admitted to Cambridge were approached for consent, either in the acute phase, or at follow-up visit. The cohort of patients recruited from Cambridge were supplemented by a convenience sample of PCR-proven COVID-19 patients from Sahlgrenska University Hospital, Sweden (February - March 2020); previously included in a prospective sampling study..$^{20}$ Written consent was gained from either patients themselves, or from their legal representatives where they lacked capacity to consent. Where written consent could not be gained due to restrictions on hospital visiting, legal representatives were consulted by telephone. This study was approved by the Swedish Ethical Review Authority (2020-01771) and the East of England - Cambridge Central Research Ethics Committee (17/EE/0025); via the Cambridge Biomedical Research Centre). Healthy controls were recruited through the Cambridge Biomedical Research Centre (prior to the COVID-19 pandemic) and all provided written consent (17/EE/0025). Data from a small positive control group consisting of patients with acute traumatic brain injury were included as a reference for the magnitude of brain injury biomarker elevations (REC 97/290).

\section{Procedures}

Serum samples were collected at up to three timepoints from admission (acute [0-14 days], subacute [15-70 days] and convalescent [at outpatient follow up; $>80$ days). The samples were aliquoted, labelled with pseudoanonymised identifiers, and frozen immediately at $-70^{\circ} \mathrm{C}$. Samples from Sweden were then shipped on dry ice to the University of Cambridge. 
medRxiv preprint doi: https://doi.org/10.1101/2021.12.03.21266112; this version posted December 5, 2021. The copyright holder for this preprint (which was not certified by peer review) is the author/funder, who has granted medRxiv a license to display the preprint in It is made available under a CC-BY-ND 4.0 International license.

\section{Demographic and clinical information}

Demographic, clinical and laboratory information was recorded by the clinical team at the time of admission; Short Form Health Survey 36 (SF36) ${ }^{21}$ was completed in patients recruited to Cambridge University Hospital who returned for follow-up after their attendance to hospital. Patients were stratified into three groups of severity based on the treatment needed in the acute phase (Mild: no supplemental oxygen was required, Moderate: supplemental oxygen was required, Severe: invasive mechanical ventilation was required).

\section{Brain injury biomarker measurement}

Neurofilament light, glial fibrillary acidic protein, total tau, and ubiquitin C-terminal hydrolase L1 concentrations were quantified in serum at the University of Cambridge using the Neurology 4-PLEX A assay run on an HD-X Analyser (Quanterix, Billerica, MA, USA). As per previous experience, UCH-L1 levels were predominantly around the lower level of quantification, with high coefficients of variance between replicates, and therefore were excluded from analysis. Five samples taken from patients within 3 days of severe traumatic brain injury were also assayed to provide a frame of reference for magnitude of changes seen.

\section{Protein microarray autoantibody profiling}

Autoantibody screening was performed using a custom central nervous system protein microarray based on the HuProt ${ }^{\mathrm{TM}}$ (version 4.0) platform. ${ }^{22,23}$ The microarray was devised in collaboration with Cambridge Protein Arrays Ltd. (Cambridge, UK) and CDI laboratories (Puerto Rico) to detect autoantibodies predominantly directed against central nervous system antigens ( $n=51$ ), but also to a number of blood-brain barrier $(n=5)$ and other tissue-specific ( $n=94$, covering organ systems including lung, heart and coagulation) antigens, as well as spike and nucleocapsid antigens (full antigen list detailed in Supplemental Figure 1). The microarrays consist of a glass microscope slide with a thin nitrocellulose coating, printed with quadruplicate spots of recombinant yeast-expressed whole proteins. Each slide accommodates up to 12 individual serum samples. Samples from healthy controls and patients with COVID-19 were randomly distributed across the slides to mitigate against experimental variation.

The slides were blocked in $2 \% \mathrm{BSA} / 0.1 \%$ PBS-Tween overnight at $4^{\circ} \mathrm{C}$, washed, and then incubated with $200 \mu \mathrm{l}$ of 1:1000 diluted serum at room temperature for two hours. The slides were washed again, incubated at room temperature for two hours with fluorophore-conjugated goat anti-human IgM- $\mu$ chain-Alexa488 (Invitrogen, Carlsbad, CA, USA, Cat. No. A21215) and goat anti-human IgG-FcDyLight550 (Invitrogen Cat. No. SA5-10135) secondary antibodies, washed, and then scanned using a Tecan LS400 scanner and GenePix Pro v4 software, with the output being median fluorescence value of the quadruplicate spots for each protein.

\section{Cytokine Profiling}

Serum concentrations of TNF $\alpha$, IL-1 $1 \beta$, IL- 6, IL-10 and IFN- $\gamma$ were quantified using by multiplexed particle based flow cytometry on a Luminex 200 analyser using xPonent Software (R\&D Systems / Luminex) according to manufacturer's recommendations. The population reference ranges derived for clinical use with this assay were utilised. Sensitivities / minimum detectable doses as indicated by the manufacturer are: IFN- $\gamma(0.04 \mathrm{pg} / \mathrm{ml}) ; \mathrm{IL}-1 \beta(0.08 \mathrm{pg} / \mathrm{ml}) ; \mathrm{IL}-6(0.14 \mathrm{pg} / \mathrm{ml}) ; \mathrm{IL} 10(0.21 \mathrm{pg} / \mathrm{ml})$; TNFa $(0.29 \mathrm{pg} / \mathrm{ml})$. 
medRxiv preprint doi: https://doi.org/10.1101/2021.12.03.21266112; this version posted December 5, 2021. The copyright holder for this preprint (which was not certified by peer review) is the author/funder, who has granted medRxiv a license to display the preprint in It is made available under a CC-BY-ND 4.0 International license.

\section{Statistical Analysis}

Continuous descriptive data are presented using median and interquartile range, and categorical variables using number and percentage. Unpaired two-group comparisons were assessed using Mann-Whitney $U$ tests, paired two-group comparisons with Wilcoxon Matched-Pairs Signed Rank tests and categorical comparisons with the Chi-squared statistic. Multiple t-tests were used to generate volcano-plots, with a false-discovery rate set to $1 \%$. Comparisons between more than two groups were undertaken using Kruskal-Wallis test with post-hoc Dunn's multiple comparison test. Correlations between continuous variables were assessed using Spearman's rank correlation coefficient, and where multiple correlations were assessed within an experiment, Bonferroni correction was used to determine the appropriate level of significance. Principal component analysis was used as a dimension reduction technique to identify inflammatory cytokine profiles. All analyses were performed using GraphPad Prism Version 9.2.0.

\section{Protein microarray data analysis}

As previously described, ${ }^{23}$ antibody binding was determined by measuring the median fluorescence intensity (MFI) of the four quadruplicate spots of each antigen; this value was then normalised by dividing it by the median MFI value of all antigens for that sample. These normalised values were then transformed into $Z$ scores based on the distribution derived for each antigen from the healthy control cohort. A positive autoantibody "hit" was defined as an antigen where $Z \geq 3$.

\section{Results}

\section{Study Populations}

For brain injury biomarker analysis, 250 samples (from 175 patients; 122 from Cambridge and 53 from Gothenburg, at up to three time-points), and control samples from 59 age-matched healthy individuals were obtained. The 122 patients from Cambridge represented $7 \%$ of a total of 1666 patients admitted over the study period. Comparisons of the study population with the overall admitted population are shown in Supplementary Figure 2. Overall, there was no difference in age between patients and controls (51 [35-61] vs. 50 [32-62], but a larger proportion of males in the patient group (93 [53\%] vs 21 [35\%]; $p=0.02$ ). Of the patients, $70(40 \%)$ had mild disease, $72(41 \%)$ moderate disease and $33(19 \%)$ severe disease. The median (IQR) timings of the samples postadmission were: acute $=7(3-10)$ days, subacute $=31(26-35)$ days, and convalescent $=122(109-$ 136). A subset of these patients underwent autoantibody and cytokine profiling. Graphical description of these cohorts is shown in Supplementary Fig. 2.

\section{Neurofilament-light (NfL) and glial fibrillary acidic protein (GFAp) rise acutely in a severity- dependant manner, whilst elevated serum total tau concentrations are seen in the convalescent period irrespective of severity}

In patients with COVID-19, serum concentrations of NfL and GFAP were raised in a severitydependant manner at both the acute and subacute timepoints; there was no systematic difference between serum total tau concentrations between patients and controls (Fig. 1A\&B, Supplementary Table 1).

The temporal dynamics, in 67 patients who provided longitudinal samples, showed that both GFAP and $\mathrm{NfL}$ tended to fall with time, although NfL rose in some patients between the acute and subacute timepoints, presumably as a result of its longer half-life (Fig. 1D; Supplementary Fig. 3A). 
medRxiv preprint doi: https://doi.org/10.1101/2021.12.03.21266112; this version posted December 5, 2021. The copyright holder for this preprint (which was not certified by peer review) is the author/funder, who has granted medRxiv a license to display the preprint in It is made available under a CC-BY-ND 4.0 International license.

Unusually, serum total tau concentrations were significantly higher than controls at the convalescent timepoint (0.95 [0.75 - 1.15] vs. 0.72 [0.60 - 1.04] pg / ml, p = 0.003; Fig. 1D \& E).

At the convalescent timepoint, serum GFAP concentrations were no higher than controls irrespective of disease-severity, but serum NfL concentrations persisted at levels which were higher in patients who had developed moderate and severe COVID-19 compared with controls (Fig. 1C, Supplementary Table 1). The elevation of serum total tau concentration did not vary with severity, and indeed after correction for multiple comparisons only patients who had developed mild disease remained significantly higher than controls (Fig. 1C, Supplementary Table 1). Convalescent levels of both NfL and GFAP concentrations correlated with paired samples taken the 15-42 day timepoint ( $\rho=0.69, p=0.0008$ and $\rho=0.82, p<0.0001$ respectively), but total Tau did not $(\rho=0.27, p=0.02$ ), suggesting that the residual elevations of $\mathrm{NfL}$ and GFAP are reflective of events occurring during the acute illness, whereas the subsequent elevation of total Tau appears to be independent from any acute effects.

To explore the relationship between elevations of convalescent brain injury biomarkers and clinical outcomes, we studied correlations with the eight components of the SF-36. High serum NfL concentrations appeared to correlate most strongly with worse scores (notably: physical functioning $[\rho=-0.52, p=0.03]$, general health $[\rho=-0.48, p=0.05]$ and role functioning - emotional $[\rho=-0.53$, $p=0.02]$ ). The relationship between serum total tau concentrations and SF-36 domains, however, was very different, with higher concentrations seemingly associating with better scores, particularly in the emotional components (emotional wellbeing $[\rho=0.56, p=0.02]$ and energy/ vitality $[\rho=0.56$, $p=0.02$ ]; Fig. 1F). None of the above comparisons withstood adjustments for multiple comparisons, however.

While the number of patients in this cohort with specific neurological syndromic diagnoses were small (mononeuritis multiplex $n=3$, opsoclonus myoclonus $n=1$, and peripheral neuropathy with concurrent encephalopathy $n=1$ ), these patients appeared to have higher brain injury biomarker levels, with one patient showing biomarker levels an order of magnitude higher than other patients. However, numbers were too small to draw definitive inferences (Supplementary Fig. 3B).

\section{Autoantibodies against a wide range of tissues are seen in COVID-19, particularly in severe disease, and associate with a proinflammatory cytokine profile}

The data were first assessed for any group-wise differences in reactivity to self-antigens between patients with COVID-19 and controls; volcano plots showed that not only did COVID-19 patients demonstrate clear IgG reactivity to SARS-CoV-2 spike protein and nucleocapsid, but also to surfactant protein A (SFTPA1), a lung surfactant protein, mutations of which result in pulmonary fibrosis (Fig. 2A). ${ }^{24}$ This increased reactivity was seen in both subacute and convalescent samples (Fig. 2B); reactivity to SFTPA1 in the subacute samples was stronger in patients with moderate and severe disease than in either those with mild disease or healthy controls (Fig. 2C). The presence of this autoantibody has not been previously described in COVID-19; furthermore, we have not detected it in cohorts of patients with traumatic brain injury (unpublished data), suggesting that it is not a common finding in critically ill patients more generally. No increased IgM reactivities were seen to any antigen in subacute COVID-19 samples compared with controls, but there was higher IgM reactivity to both spike protein and HLA-DRA in the convalescent samples. 
medRxiv preprint doi: https://doi.org/10.1101/2021.12.03.21266112; this version posted December 5, 2021. The copyright holder for this preprint (which was not certified by peer review) is the author/funder, who has granted medRxiv a license to display the preprint in

It is made available under a CC-BY-ND 4.0 International license .

While the group level comparisons provided information about pervasive autoantibody responses that were common across patients, this approach was less useful in identifying autoantibody responses which were found in a minority of patients but were still biologically interesting. Autoantibody profiles of the groups were therefore compared by assessing the number and targets of positive autoantibody hits to specific target antigens. COVID-19 patients had higher numbers of both IgG and IgM autoantibody hits than healthy controls, which peaked at the subacute timepoint, but remained elevated in the convalescent samples (Fig. 2D\&E). Patients with moderate or severe disease had higher numbers of autoantibody hits than those with mild disease at the subacute timepoint (Fig. 2F\&G), and the number of IgM and IgG autoantibodies an individual had were related $(\rho=0.32, p=0.01)$.

Autoantibodies to many different antigens were seen, but some were seen more frequently (Fig. 2H). Anti-myelin associated glycoprotein (MAG) was the most commonly detected IgG autoantibody, seen in 9.6\% COVID-19 samples but not seen in any healthy controls, followed by surfactant protein A (SFTPA1), which was detected in $8.8 \%$ patients, and again not seen in healthy controls (Frequency of positive autoantibody hits in control and COVID-19 cohorts shown in Supplementary Table 2). No specifically characteristic autoantibody was seen in the five patients with syndromic neurological diagnoses.

Elevations in serum cytokine concentrations were seen in the subacute samples, particularly IL-6, TNF $\alpha$ and IL-10, but many patients demonstrated concentrations persisting above the normal range in the convalescent samples. (Fig. 2I). There was substantial covariance between all cytokines other than interferon gamma (Fig. 2J), but principal component analysis demonstrated the three canonical pro-inflammatory cytokines driving PC1 (Fig. 2K; note that the proinflammatory cytokines generate a negative eigenvector [Fig. 2L]). Patients with moderate and severe disease demonstrated higher concentrations of proinflammatory cytokines (Fig. 2M). The number of both IgG and IgM hits correlated with an elevated proinflammatory cytokine response (PC1 from principal component analysis vs. IgG: $\rho=-0.33, p=0.01, P C 1$ vs. IgM: $\rho=-0.30, p=0.02$ ).

\section{Magnitude of autoantibody and pro-inflammatory cytokine response associates with high serum markers of brain injury}

To understand whether there was a relationship between inflammatory profiles and brain injury biomarkers, we compared brain injury biomarker levels with cytokines and autoantibody responses. At the subacute timepoint, serum GFAP and NfL concentrations positively correlated with both the number of IgG hits and increased proinflammatory cytokine responses (GFAP and NfL vs. IgG hits: $\rho=$ $0.26, p=0.03$ and $\rho=0.38, p=0.001$ respectively [Fig. 3A\&B]; GFAP and NfL vs. cytokine PC1 $\rho=-$ $0.53, p<0.0001$ and $\rho=-0.65, p<0.0001$ respectively), but there was no such relationship between serum total Tau concentration and number of $\lg G$ hits or cytokine response $(\rho=0.02, p=0.90$ and $\rho$ $=0.17, p=0.2)$. The number of IgM hits also correlated with serum NfL concentration $(\rho=0.33, p=$ 0.006 ), but not with GFAP or total Tau ( $\rho=0.20, p=0.10$, and $\rho=0.07, p=0.57$ respectively). The relationship between brain injury biomarkers and the top 10 most frequently detected autoantibodies was investigated; after Bonferroni correction, serum NfL concentrations were associated with the $Z$ score of IgG autoantibodies against NfL, SFTPA1 and MYBPHL $(\rho=0.35, p=$ $0.002, \rho=0.38, p=0.001$ and $\rho=0.41, p=0.0005$ respectively), but none of the top 10 autoantibodies retained significance against serum GFAP or total Tau concentrations after correcting for multiple comparisons.

In the convalescent period, the number of IgG hits once again correlated with serum $\mathrm{NfL}$ concentrations ( $\rho=0.48, p=0.002$; Fig. $3 C$ ), but not GFAP or total tau $(\rho=0.12, p=0.46, \rho=-0.08, p$ 
medRxiv preprint doi: https://doi.org/10.1101/2021.12.03.21266112; this version posted December 5, 2021. The copyright holder for this preprint (which was not certified by peer review) is the author/funder, who has granted medRxiv a license to display the preprint in It is made available under a CC-BY-ND 4.0 International license.

$=0.63$ respectively). The relationship between brain injury biomarkers and cytokine profiles seen in the acute phase was replicated in convalescent patients, with elevations in proinflammatory cytokines associating with raised NfL and GFAP, but not total tau (PC1 vs. NfL: $\rho=-0.55, p<0.0001$; GFAP: $\rho=-0.26, p=0.05$; total Tau $\rho=-0.1, p=0.43$ ).

\section{IgM autoantibodies in the convalescent phase are associated with elevation of brain injury biomarkers, especially Tau}

At the convalescent timepoint, however, there was an association between number of IgM hits and all brain injury biomarkers, particularly total Tau (GFAP: $\rho=0.45, p=0.004 ; \mathrm{NfL}: \rho=0.50, p=0.001$; total Tau: $\rho=0.51, p=0.0007$; Fig. 3D). To investigate this relationship further, patients were dichotomised into either high IgM responder ( $\geq 3$ IgM hits) versus low IgM responder (<3 IgM Hits) groups, and the levels of brain-injury biomarkers compared. Serum concentrations of all three biomarkers were higher in the high IgM responder group, but again total Tau was the most highly significant difference (GFAP: 58.2 [32.6 - 87.05] vs. 37.8 [23.8 - 43.1], $p=0.03$; NfL: 7.5 [5.2 - 16.5] vs. $4.6[3.0-8.1], p=0.026$; total Tau: $1.1[0.9-1.3]$ vs. $0.8[0.7-0.9], p=0.001$; Fig. 3E).

\section{Discussion}

The aim of this study was to examine how frequently brain injury occurred in COVID-19, both acutely and in convalescence, and whether elevated brain injury biomarkers were associated with a dysregulated host inflammatory response. We demonstrated that brain injury biomarkers are elevated in a severity-dependent manner in the acute phase, and that these elevations are associated with both raised pro-inflammatory cytokines and the presence of autoantibodies. When patients were followed up ( $\sim$ four months post-admission), there was evidence that this immunological dysregulation had not fully resolved and was associated with serum markers of ongoing active brain injury (namely neurofilament light-chain), albeit to a lesser degree than in the acute illness. In addition, in convalescent patients, there appeared to be a second, separate, process, which was characterised by a different pattern of serum brain injury biomarkers (more specifically elevation of total Tau), which were not related to initial COVID-19 severity or pro-inflammatory cytokine levels but were associated with the presence of IgM autoantibodies. We observed autoantibody responses to many different targets (most commonly lung surfactant protein A1 and myelin associated glycoprotein), but the particular target of the autoantibody did not seem to relate to the presence of brain injury; rather, it seemed that the more diverse the autoantibody repertoire generated (reflecting a more generalised immune response), the more significant the degree of brain injury.

Our data confirms and extends previous studies investigating brain injury biomarkers in COVID-19, which have suggested that blood NfL concentrations are elevated in acute COVID-19 infection, and associate with severity of illness and therefore poor outcome. ${ }^{5-15} \mathrm{~A}$ longitudinal cohort study by members in our collaboration, demonstrated that serum NfL and GFAP levels had returned to baseline by six months following admission, ${ }^{7}$ suggesting that the persistent elevation in $\mathrm{NLL}$ at four months in our cohort is capturing the end of this period of active brain injury. The late elevations in total Tau seen in our cohort, however, are novel, as there is no precedent in the COVID-19 literature for this. Elevated serum total Tau concentrations have been described in patients with tauopathies such as Alzheimer's Disease and Frontotemporal dementia, ${ }^{25}$ and serum concentrations associate with trajectory of cognitive decline in these conditions. ${ }^{26,27}$ Larger cohorts will be required to accurately delineate the association between late elevated total Tau and clinical outcome, however 
medRxiv preprint doi: https://doi.org/10.1101/2021.12.03.21266112; this version posted December 5, 2021. The copyright holder for this preprint (which was not certified by peer review) is the author/funder, who has granted medRxiv a license to display the preprint in It is made available under a CC-BY-ND 4.0 International license.

the lack of association between initial disease severity and subsequent total Tau elevation is tantalising: if replicated, this may represent an accessible biomarker to explore the basis of the protracted neuropsychological sequelae that occurs in a substantial minority of people infected with SARS-CoV-2.

It is well recognised that viral infections can trigger autoantibody production, both low-affinity polyreactive species, as well as higher-affinity specific species such as anti-cardiolipin antibodies. ${ }^{28,29}$ This phenomenon has been replicated in COVID-19, with a number of studies describing the presence of autoantibodies to a plethora of targets including "traditional" rheumatological autoantibodies as well as less clinically established autoantibodies such as those targeting type 1 interferons. ${ }^{30-35}$ The role of these autoantibodies is largely unknown. Although they appear to occur more commonly in severe illness, they may well simply represent an epiphenomenon of tissue damage (perhaps even a useful mechanism for debris clearance). However, it has been suggested that autoantibodies to certain targets (such as interferons) may predispose to severe disease ${ }^{36}$ and it appears that immune-complex formation is a potent driver of secondary immune cell activation in COVID-19. ${ }^{37}$

The associations seen in our data between brain injury biomarkers and dysregulation of both innate and adaptive immune responses may represent autoinflammatory and autoimmune mechanisms that drive neurological injury. The well-documented impact of immune modulatory treatments in preventing severe COVID-19 provides strong evidence that a substantial component of the acute pathophysiology of COVID-19 relates to an unbridled and dysregulated host response, rather than damage caused directly by the virus. Our data suggest that brain injury occurring during acute COVID-19 may also result from similar mechanisms, and provide a plausible mechanistic basis for these manifestations, given the scant evidence to support direct viral invasion of the brain by SARSCoV-2. ${ }^{1}$

Our data do not define causality between the immunological parameters and the presence of brain injury. In the acute phase, both may be influenced by additional factors that drive severe disease. Indeed, the immunological changes may be occurring in response to tissue injury, rather than causing it. However, given the growing evidence of the detrimental effects of excess inflammation in COVID-19 more broadly, it is plausible that the elevation of brain injury biomarkers is driven by a maladaptive host response. ${ }^{38}$ This may be the result of neuroinflammation per se, ${ }^{39-42}$ or inflammatory injury to the cerebrovascular bed, which subsequently results in microvascular ischaemic brain injury. ${ }^{43-46}$ Similar considerations may apply to the convalescent phase of illness, where the association of IgM autoantibodies with serum Tau could represent a persisting immunological dyscrasia driving brain injury. The relative specificity of Tau at this phase of the illness may represent tissue specificity of the process (Tau is a dendritic and axonal marker).

It should be noted that this study does not contain a disease control group consisting of patients with alternative respiratory infections, such as influenza, to determine to what degree the brain injury biomarkers and immunological changes are seen in other comparable conditions. A single small study suggested that patients with bacterial pneumonia displayed higher blood markers of brain injury than patients with COVID-19, ${ }^{9}$ and we hypothesis that the processes described in this paper are likely to be relevant to severe illness more broadly. This being the case, the lessons learnt from COVID-19 may serve to help mitigate against the neurological sequelae of severe illness in the future. ${ }^{47}$

In conclusion, we have demonstrated that markers of brain injury are associated with dysregulated immunological responses in COVID-19, and that there may be a separate late process irrespective of 
medRxiv preprint doi: https://doi.org/10.1101/2021.12.03.21266112; this version posted December 5, 2021. The copyright holder for this preprint (which was not certified by peer review) is the author/funder, who has granted medRxiv a license to display the preprint in It is made available under a CC-BY-ND 4.0 International license.

initial disease severity which is characterised by elevated serum total Tau concentrations and the presence of IgM autoantibodies.

\section{Acknowledgements}

We thank all the healthcare professionals who were involved in the care of the patients recruited to this study, and particularly thank all the patients who took part.

We thank NIHR BioResource volunteers for their participation, and gratefully acknowledge NIHR BioResource centres, NHS Trusts and staff for their contribution. We thank the National Institute for Health Research, NHS Blood and Transplant, and Health Data Research UK as part of the Digital Innovation Hub Programme. The views expressed are those of the author(s) and not necessarily those of the NHS, the NIHR or the Department of Health and Social Care.

These studies were supported largely by the NIHR Cambridge Biomedical Centre and by NIHR funding to the NIHR BioResource (RG94028 \& RG85445).

B.D.M. is supported by grants from the Medical Research Council (MR/V007181/1 and MR/T028750/1) and Wellcome (ISSF201902/3)

EN, DKM and AC are supported by Brain Research UK.

$\mathrm{HZ}$ is a Wallenberg Scholar supported by grants from the Swedish Research Council (\#2018-02532), the European Research Council (\#681712), Swedish State Support for Clinical Research (\#ALFGBG720931), the Alzheimer Drug Discovery Foundation (ADDF), USA (\#201809-2016862), the AD Strategic Fund and the Alzheimer's Association (\#ADSF-21-831376-C, \#ADSF-21-831381-C and \#ADSF-21-831377-C), the Olav Thon Foundation, the Erling-Persson Family Foundation, Stiftelsen för Gamla Tjänarinnor, Hjärnfonden, Sweden (\#FO2019-0228), the European Union's Horizon 2020 research and innovation programme under the Marie Skłodowska-Curie grant agreement No 860197 (MIRIADE), and the UK Dementia Research Institute at UCL.

MG is supported by the Swedish State Support for Clinical Research ( ALFGBG-717531) and by grants from the SciLifeLab National COVID-19 Research Program, financed by the Knut and Alice Wallenberg Foundation (KAW 2020.0182 and 2020.0241).

GB is supported by a sabbatical grant from PASPA-DGAPA-UNAM, México.

SRI is supported by a Wellcome Trust Fellowship [104079/Z/14/Z], a Medical Research Council Fellowship [MR/V007173/1], BMA Research Grants- Vera Down grant (2013) and Margaret Temple (2017), Epilepsy Research UK (P1201), the Fulbright UK-US commission (MS-Society research award) and by the NIHR Oxford Biomedical Research Centre. The views expressed are those of the author(s) and not necessarily those of the NHS, the NIHR or the Department of Health. For the purpose of Open Access, the author has applied a CC BY public copyright licence to any Author Accepted Manuscript version arising from this submission.

VFJN is an Academy of Medical Sciences / The Health Foundation Clinician Scientist.

EB is supported by an NIHR Senior Investigator award

DKM is supported by an NIHR Senior Investigator Award and European Union 7th Framework program 
medRxiv preprint doi: https://doi.org/10.1101/2021.12.03.21266112; this version posted December 5, 2021. The copyright holder for this preprint (which was not certified by peer review) is the author/funder, who has granted medRxiv a license to display the preprint in

It is made available under a CC-BY-ND 4.0 International license .

We would like to thank Addenbrooke's Charitable Trust and the NIHR Cambridge Biomedical Research Centre for their funding, and the NIHR Cambridge Clinical Research Facility outreach team for enrolment of patients.

The members of the NIHR COVID-19 BioResource are John Allison, Gisele Alvio, Ali Ansaripour, Sharon Baker, Stephen Baker, Laura Bergamaschi, Areti Bermperi, Ariana Betancourt, Heather Biggs, Sze-How Bong, Georgie Bower, John R. Bradley, Karen Brookes, Ashlea Bucke, Ben Bullman, Katherine Bunclark, Helen Butcher, Sarah Caddy, Jo Calder, Laura Caller, Laura Canna, Daniela Caputo, Matt Chandler, Yasmin Chaudhry, Patrick Chinnery, Debbie Clapham-Riley, Daniel Cooper, Chiara Cossetti, Cherry Crucusio, Isabel Cruz, Martin Curran, Jerome D. Coudert, Eckart M.D.D. De Bie, Rnalie De Jesus, Aloka De Sa, Anne-Maree Dean, Katie Dempsey, Eleanor Dewhurst, Giovanni di Stefano, Jason Domingo, Gordon Dougan, Benjamin J. Dunmore, Anne Elmer, Madeline Epping, Codie Fahey, Stuart Fawke, Theresa Feltwell, Christian Fernandez, Stewart Fuller, Anita Furlong, Iliana Georgana, Anne George, Nick Gleadall, lan G Goodfellow, Stefan Gräf, Barbara Graves, Jennifer Gray, Richard Grenfell, Ravindra K. Gupta, Grant Hall, William Hamilton, Julie Harris, Sabine Hein, Christoph Hess, Sarah Hewitt, Andrew Hinch, Josh Hodgson, Myra Hosmillo, Elaine Holmes, Charlotte Houldcroft, Christopher Huang, Oisín Huhn, Kelvin Hunter, Tasmin Ivers, Aminu Jahun, Sarah Jackson, Isobel Jarvis, Emma Jones, Heather Jones, Sherly Jose, Maša Josipović, Mary Kasanicki, Jane Kennet, Fahad Khokhar, Yvonne King, Nathalie Kingston, Jenny Kourampa, Emma Le Gresley, Elisa Laurenti, Ekaterina Legchenko, Paul J. Lehner, Daniel Lewis, Emily Li, Rachel Linger, Paul A. Lyons, Michael Mackay, John C. Marioni, Jimmy Marsden, Jennifer Martin, Cecilia Matara, Nicholas J. Matheson, Caroline McMahon, Anne Meadows, Sarah Meloy, Vivien Mendoza, Luke Meredith, Nicole Mende, Federica Mescia, Alice Michael, Alexei Moulton, Rachel Michel, Lucy Mwaura, Francesca Muldoon, Francesca Nice, Criona O'Brien, Charmain Ocaya, Ciara O'Donnell, Georgina Okecha, Ommar Omarjee, Nigel Ovington, Willem H. Owehand, Sofia Papadia, Roxana Paraschiv, Surendra Parmar, Ciro Pascuale, Caroline Patterson, Christopher Penkett, Marlyn Perales, Marianne Perera, Isabel Phelan, Malte Pinckert, Linda Pointon, Petra Polgarova, Gary Polwarth, Nicole Pond, Jane Price, Venkatesh Ranganath, Cherry Publico, Rebecca Rastall, Carla Ribeiro, Nathan Richoz, Veronika Romashova, Sabrina Rossi, Jane Rowlands, Valentina Ruffolo, Jennifer Sambrook, Caroline Saunders, Natalia Savinykh Yarkoni, Katherine Schon, Mayurun Selvan, Rahul Sharma, Joy Shih, Kenneth G.C. Smith, Sarah Spencer, Luca Stefanucci, Hannah Stark, Jonathan Stephens, Kathleen E Stirrups, Mateusz Strezlecki, Charlotte Summers, Rachel Sutcliffe, James E.D. Thaventhiran, Tobias Tilly, Zhen Tong, Hugo Tordesillas, Carmen Treacy, Mark Toshner, Paul Townsend, Carmen Treacy, Lori Turner, Phoebe Vargas, Bensi Vergese, Julie von Ziegenweidt, Neil Walker, Laura Watson, Jennifer Webster, Michael P. Weekes, Nicola K. Wilson, Jennifer Wood, Jieniean Worsley, Marta Wylot, Anna Yakovleva, Cissy Yong and Julie-Anne Zerrudo.

\section{Conflicts of interest}

$\mathrm{HZ}$ has served at scientific advisory boards and/or as a consultant for Abbvie, Alector, Annexon, AZTherapies, CogRx, Denali, Eisai, Nervgen, Pinteon Therapeutics, Red Abbey Labs, Roche, Samumed, Siemens Healthineers, Triplet Therapeutics, and Wave, has given lectures in symposia sponsored by Cellectricon, Fujirebio, Alzecure and Biogen, and is a co-founder of Brain Biomarker Solutions in Gothenburg AB (BBS), which is a part of the GU Ventures Incubator Program.

MG has received research grants from Gilead Sciences and Janssen-Cilag and honoraria as speaker and/or scientific advisor from Amgen, Biogen, Bristol-Myers Squibb, Gilead Sciences, GlaxoSmithKline/ViiV, Janssen-Cilag, MSD, Novocure, and Novo Nordic

SRI is a coapplicant and receives royalties on patent application WO/210/046716 (U.K. patent no., PCT/GB2009/051441) entitled 'Neurological Autoimmune Disorders' (licensed for the development 
medRxiv preprint doi: https://doi.org/10.1101/2021.12.03.21266112; this version posted December 5, 2021. The copyright holder for this preprint (which was not certified by peer review) is the author/funder, who has granted medRxiv a license to display the preprint in

It is made available under a CC-BY-ND 4.0 International license .

of assays for LGI1 and other VGKC-complex antibodies) and 'Diagnostic Strategy to improve specificity of CASPR2 antibody detection. (PCT/G82019 /051257). SRI has received honoraria and/or research support from UCB, Immunovant, MedImmun, Roche, Cerebral therapeutics, CSL Behring, ONO Pharma and ADC therapeutics.

VFJN holds a grant from Roche Pharmaceuticals on proteomic biomarkers in traumatic brain injury.

EB serves on the scientific advisory board of Sosei Hepatares and as a consultant for GSK.

MT is the founder and CEO of Cambridge Protein Arrays Ltd.

DKM reports grants, personal fees, and nonfinancial support from GlaxoSmithKline Ltd.; grants, personal fees, and other from NeuroTrauma Sciences; grants and personal fees from Integra Life Sciences; personal fees from Pfizer Ltd.; grants and personal fees from Lantmannen AB; from Calico Ltd.; personal fees from Pressura Neuro Ltd.; and others from Cortirio Ltd., outside the submitted work.

AJC received honoraria and travel expenses from Genzyme (a Sanofi company) until September 2017.

VFJN reports personal fees from Neurodiem, outside the submitted work.

\section{References}

1 Ren AL, Digby RJ, Needham EJ. Neurological update: COVID-19. J Neurol 2021; published online April 30. DOI:10.1007/s00415-021-10581-y.

2 Zayet S, Zahra H, Royer P-Y, et al. Post-COVID-19 Syndrome: Nine Months after SARS-CoV-2 Infection in a Cohort of 354 Patients: Data from the First Wave of COVID-19 in Nord FrancheComté Hospital, France. Microorganisms 2021; 9: 1719.

3 Malik P, Patel K, Pinto C, et al. Post-acute COVID-19 syndrome (PCS) and health-related quality of life (HRQoL)-A systematic review and meta-analysis. Journal of Medical Virology; $\mathbf{n} / \mathbf{a}$. DOI:10.1002/jmv.27309.

4 Whitaker M, Elliott J, Chadeau-Hyam M, et al. Persistent symptoms following SARS-CoV-2 infection in a random community sample of 508,707 people. 2021.

5 Paterson RW, Benjamin LA, Mehta PR, et al. Serum and cerebrospinal fluid biomarker profiles in acute SARS-CoV-2-associated neurological syndromes. Brain Commun 2021; 3: fcab099.

6 Bozzetti S, Ferrari S, Zanzoni S, et al. Neurological symptoms and axonal damage in COVID-19 survivors: are there sequelae? Immunol Res $2021 ;$ : $1-5$.

7 Kanberg N, Simrén J, Edén A, et al. Neurochemical signs of astrocytic and neuronal injury in acute COVID-19 normalizes during long-term follow-up. EBioMedicine 2021; 70: 103512.

8 Prudencio $\mathrm{M}$, Erben $\mathrm{Y}$, Marquez $\mathrm{CP}$, et al. Serum neurofilament light protein correlates with unfavorable clinical outcomes in hospitalized patients with COVID-19. Sci Transl Med 2021; 13: eabi7643. 
medRxiv preprint doi: https://doi.org/10.1101/2021.12.03.21266112; this version posted December 5, 2021. The copyright holder for this preprint (which was not certified by peer review) is the author/funder, who has granted medRxiv a license to display the preprint in

It is made available under a CC-BY-ND 4.0 International license .

9 Chung H, Neu C, Wickel J, Kuckertz SL, Coldewey SM. Neurofilament Light Chain in Patients with COVID-19 and Bacterial Pneumonia. Ann Neurol 2021; 90: 174-5.

10 De Lorenzo R, Loré NI, Finardi A, et al. Blood neurofilament light chain and total tau levels at admission predict death in COVID-19 patients. J Neurol 2021; : 1-7.

11 Aamodt AH, Høgest $\varnothing \mathrm{l}$ EA, Popperud TH, et al. Blood neurofilament light concentration at admittance: a potential prognostic marker in COVID-19. J Neurol 2021; : 1-10.

12 Sutter R, Hert L, De Marchis GM, et al. Serum Neurofilament Light Chain Levels in the Intensive Care Unit: Comparison between Severely III Patients with and without Coronavirus Disease 2019. Ann Neurol 2021; 89: 610-6.

13 Virhammar J, Nääs A, Fällmar D, et al. Biomarkers for central nervous system injury in cerebrospinal fluid are elevated in COVID-19 and associated with neurological symptoms and disease severity. Eur J Neurol 2020; published online Dec 28. DOI:10.1111/ene.14703.

14 Ameres M, Brandstetter S, Toncheva AA, et al. Association of neuronal injury blood marker neurofilament light chain with mild-to-moderate COVID-19. J Neurol 2020; 267: 3476-8.

15 Kanberg N, Ashton NJ, Andersson L-M, et al. Neurochemical evidence of astrocytic and neuronal injury commonly found in COVID-19. Neurology 2020; 95: e1754-9.

16 van Paassen J, Vos JS, Hoekstra EM, Neumann KMI, Boot PC, Arbous SM. Corticosteroid use in COVID-19 patients: a systematic review and meta-analysis on clinical outcomes. Crit Care 2020; 24: 696.

17 Nissen CB, Sciascia S, de Andrade D, et al. The role of antirheumatics in patients with COVID-19. Lancet Rheumatol 2021; 3: e447-59.

18 Ramos-Casals M, Brito-Zerón P, Mariette X. Systemic and organ-specific immune-related manifestations of COVID-19. Nat Rev Rheumatol 2021; 17: 315-32.

19 Szekanecz Z, McInnes IB, Schett G, Szamosi S, Benkő S, Szűcs G. Autoinflammation and autoimmunity across rheumatic and musculoskeletal diseases. Nat Rev Rheumatol 2021; 17: 58595.

20 Marklund E, Leach S, Axelsson $\mathrm{H}$, et al. Serum-IgG responses to SARS-CoV-2 after mild and severe COVID-19 infection and analysis of IgG non-responders. PLoS One 2020; 15: e0241104.

21 Contopoulos-loannidis DG, Karvouni A, Kouri I, loannidis JPA. Reporting and interpretation of SF36 outcomes in randomised trials: systematic review. BMJ 2009; 338: a3006.

22 Jeong JS, Jiang L, Albino E, et al. Rapid Identification of Monospecific Monoclonal Antibodies Using a Human Proteome Microarray. Mol Cell Proteomics 2012; 11.

DOI:10.1074/mcp.0111.016253.

23 Needham EJ, Stoevesandt O, Thelin EP, et al. Complex Autoantibody Responses Occur following Moderate to Severe Traumatic Brain Injury. The Journal of Immunology 2021; published online June 18. DOI:10.4049/jimmunol.2001309.

24 Kristof AS. Novel rare genetic variants in idiopathic pulmonary fibrosis. Eur Respir J 2020; 56: 2003252. 
medRxiv preprint doi: https://doi.org/10.1101/2021.12.03.21266112; this version posted December 5, 2021. The copyright holder for this preprint (which was not certified by peer review) is the author/funder, who has granted medRxiv a license to display the preprint in

It is made available under a CC-BY-ND 4.0 International license .

25 Wilczyńska K, Waszkiewicz N. Diagnostic Utility of Selected Serum Dementia Biomarkers: Amyloid ß-40, Amyloid ß-42, Tau Protein, and YKL-40: A Review. J Clin Med 2020; 9: 3452.

26 Rajan KB, Aggarwal NT, McAninch EA, et al. Remote Blood Biomarkers of Longitudinal Cognitive Outcomes in a Population Study. Ann Neurol 2020; 88: 1065-76.

27 Mielke MM, Hagen CE, Wennberg AMV, et al. Association of Plasma Total Tau Level With Cognitive Decline and Risk of Mild Cognitive Impairment or Dementia in the Mayo Clinic Study on Aging. JAMA Neurol 2017; 74: 1073-80.

28 Hansen KE, Arnason J, Bridges AJ. Autoantibodies and common viral illnesses. Seminars in Arthritis and Rheumatism 1998; 27: 263-71.

29 Barzilai O, Ram M, Shoenfeld Y. Viral infection can induce the production of autoantibodies. Curr Opin Rheumatol 2007; 19: 636-43.

30 Chang SE, Feng A, Meng W, et al. New-onset IgG autoantibodies in hospitalized patients with COVID-19. Nat Commun 2021; 12: 5417.

31 Vlachoyiannopoulos PG, Magira E, Alexopoulos H, et al. Autoantibodies related to systemic autoimmune rheumatic diseases in severely ill patients with COVID-19. Ann Rheum Dis 2020; 79: 1661-3.

32 Arthur JM, Forrest JC, Boehme KW, et al. Development of ACE2 autoantibodies after SARS-CoV-2 infection. PLoS One 2021; 16: e0257016.

33 Goncalves D, Mezidi M, Bastard P, et al. Antibodies against type I interferon: detection and association with severe clinical outcome in COVID-19 patients. Clin Transl Immunology 2021; 10: e1327.

34 van der Wijst MGP, Vazquez SE, Hartoularos GC, et al. Type I interferon autoantibodies are associated with systemic immune alterations in patients with COVID-19. Sci Trans/ Med 2021; : eabh2624.

35 Richter AG, Shields AM, Karim A, et al. Establishing the prevalence of common tissue-specific autoantibodies following severe acute respiratory syndrome coronavirus 2 infection. Clin Exp Immunol 2021; 205: 99-105.

36 Bastard P, Gervais A, Le Voyer T, et al. Autoantibodies neutralizing type I IFNs are present in $4 \%$ of uninfected individuals over 70 years old and account for $\sim 20 \%$ of COVID-19 deaths. Science Immunology 2021; 6: eabl4340.

37 Mazzitelli I, Bleichmar L, Ludueña MG, et al. IgG immune complexes may contribute to neutrophil activation in the course of severe COVID-19. J Infect Dis 2021; : jiab174.

38 Edén A, Simrén J, Price RW, Zetterberg H, Gisslén M. Neurochemical biomarkers to study CNS effects of COVID-19: A narrative review and synthesis. J Neurochem 2021; 159: 61-77.

39 Matschke J, Lütgehetmann M, Hagel C, et al. Neuropathology of patients with COVID-19 in Germany: a post-mortem case series. Lancet Neurol 2020; 19: 919-29.

40 von Weyhern $\mathrm{CH}$, Kaufmann I, Neff F, Kremer M. Early evidence of pronounced brain involvement in fatal COVID-19 outcomes. Lancet 2020; 395: e109. 
medRxiv preprint doi: https://doi.org/10.1101/2021.12.03.21266112; this version posted December 5, 2021. The copyright holder for this preprint (which was not certified by peer review) is the author/funder, who has granted medRxiv a license to display the preprint in It is made available under a CC-BY-ND 4.0 International license .

41 Westhoff D, Engelen-Lee JY, Hoogland ICM, et al. Systemic infection and microglia activation: a prospective postmortem study in sepsis patients. Immun Ageing 2019; 16. DOI:10.1186/s12979019-0158-7.

42 Mazeraud A, Righy C, Bouchereau E, Benghanem S, Bozza FA, Sharshar T. Septic-Associated Encephalopathy: a Comprehensive Review. Neurotherapeutics 2020; 17: 392-403.

43 Conklin J, Frosch MP, Mukerji SS, et al. Susceptibility-weighted imaging reveals cerebral microvascular injury in severe COVID-19. J Neurol Sci 2021; 421: 117308.

44 Fernández S, Palomo M, Molina $\mathrm{P}$, et al. Progressive endothelial cell damage in correlation with sepsis severity. Defibrotide as a contender. J Thromb Haemost 2021; 19: 1948-58.

45 Varga Z, Flammer AJ, Steiger $\mathrm{P}$, et al. Endothelial cell infection and endotheliitis in COVID-19. The Lancet 2020; 395: 1417-8.

46 Zhou Y, Xu J, Hou Y, et al. Network medicine links SARS-CoV-2/COVID-19 infection to brain microvascular injury and neuroinflammation in dementia-like cognitive impairment. Alzheimers Res Ther 2021; 13: 110.

47 Inoue S, Hatakeyama J, Kondo Y, et al. Post-intensive care syndrome: its pathophysiology, prevention, and future directions. Acute Med Surg 2019; 6: 233-46. 
medRxiv preprint doi: https://doi.org/10.1101/2021.12.03.21266112; this version posted December 5, 2021. The copyright holder for this preprint (which was not certified by peer review) is the author/funder, who has granted medRxiv a license to display the preprint in

It is made available under a CC-BY-ND 4.0 International license.

A

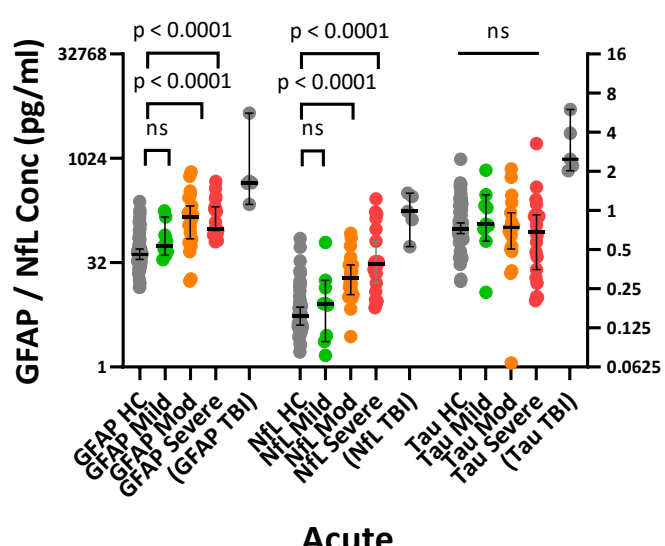

C

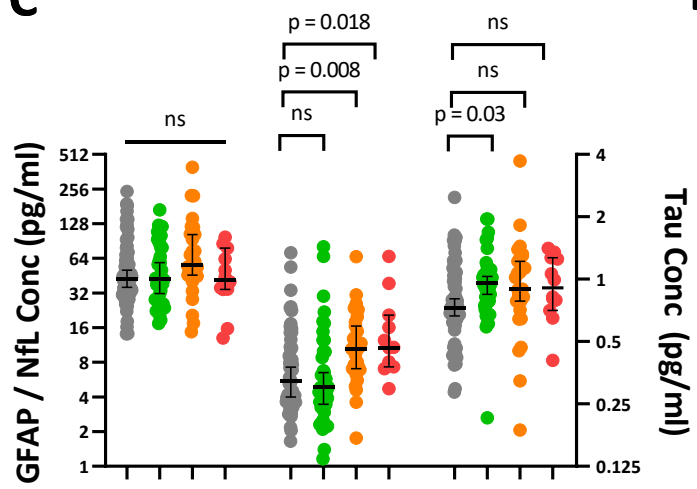

$\mathbf{E}$

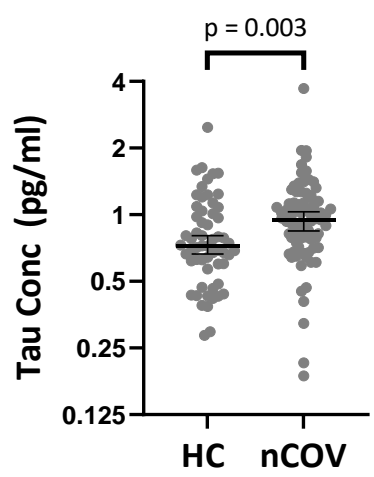

\section{Convalescent}

B

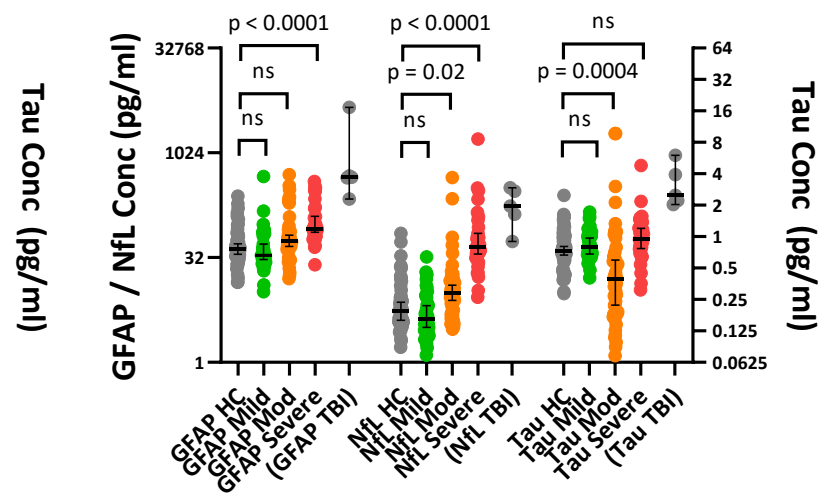

Subacute

D GFAP

NfL

Tau
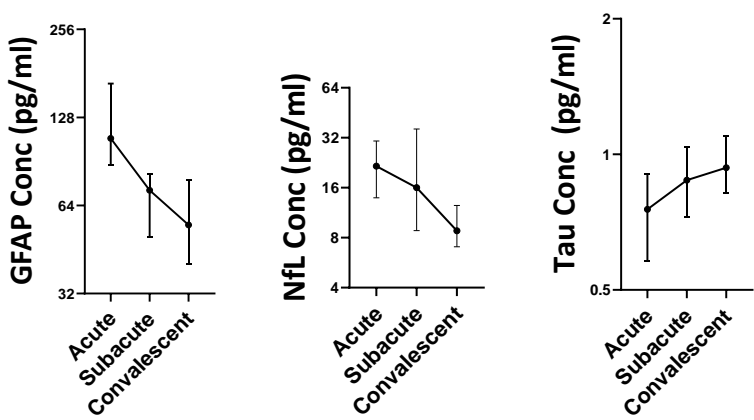

F

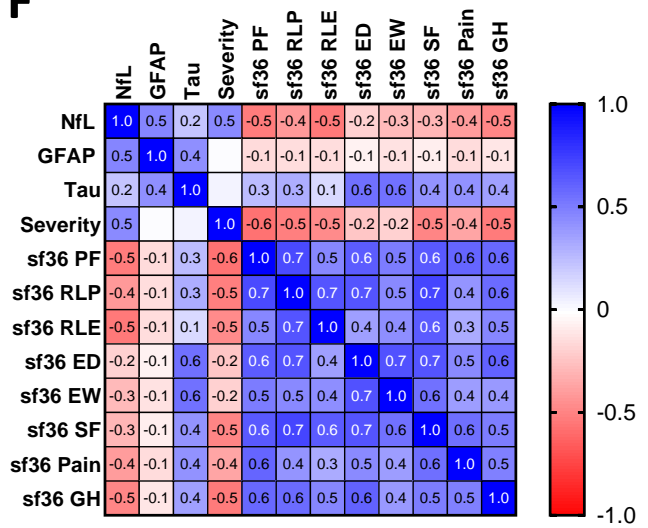


medRxiv preprint doi: https://doi.org/10.1101/2021.12.03.21266112; this version posted December 5, 2021. The copyright holder for this preprint (which was not certified by peer review) is the author/funder, who has granted medRxiv a license to display the preprint in It is made available under a CC-BY-ND 4.0 International license .

Figure 1. Serum brain injury biomarker concentrations in patients with COVID-19. A-C) Dotplots showing the effect of COVID-19 disease severity on brain injury biomarkers at the acute, subacute and convalescent timepoints; representative levels from five patients with acute severe traumatic brain injury (TBI) included as a reference for magnitude of elevation. D) Temporal changes in serum GFAP, NfL and Tau concentrations. E) Elevated serum total Tau concentrations at the convalescent timepoint in COVID-19. F) Correlation matrix of brain injury biomarkers and SF36 quality of life measure components

$H C=$ healthy controls, $n C O V=$ COVID-19, TBI = traumatic brain injury, CNS = central nervous system complication, $P N S=$ peripheral nervous system complication. Multiple group comparisons are by Kruskal-Wallis test with post-hoc Dunn's multiple comparison test; two-group unpaired comparisons are by Mann-Whitney $U$ test, and paired by Wilcoxon matched-pairs signed rank test; correlations are by Spearman's rank. 
medRxiv preprint doi: https://doi.org/10.1101/2021.12.03.21266112; this version posted December 5, 2021. The copyright holder for this preprint (which was not certified by peer review) is the author/funder, who has granted medRxiv a license to display the preprint in It is made available under a CC-BY-ND 4.0 International license .

A

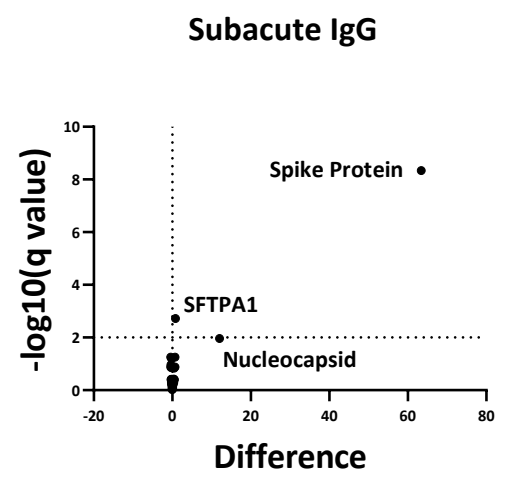

D
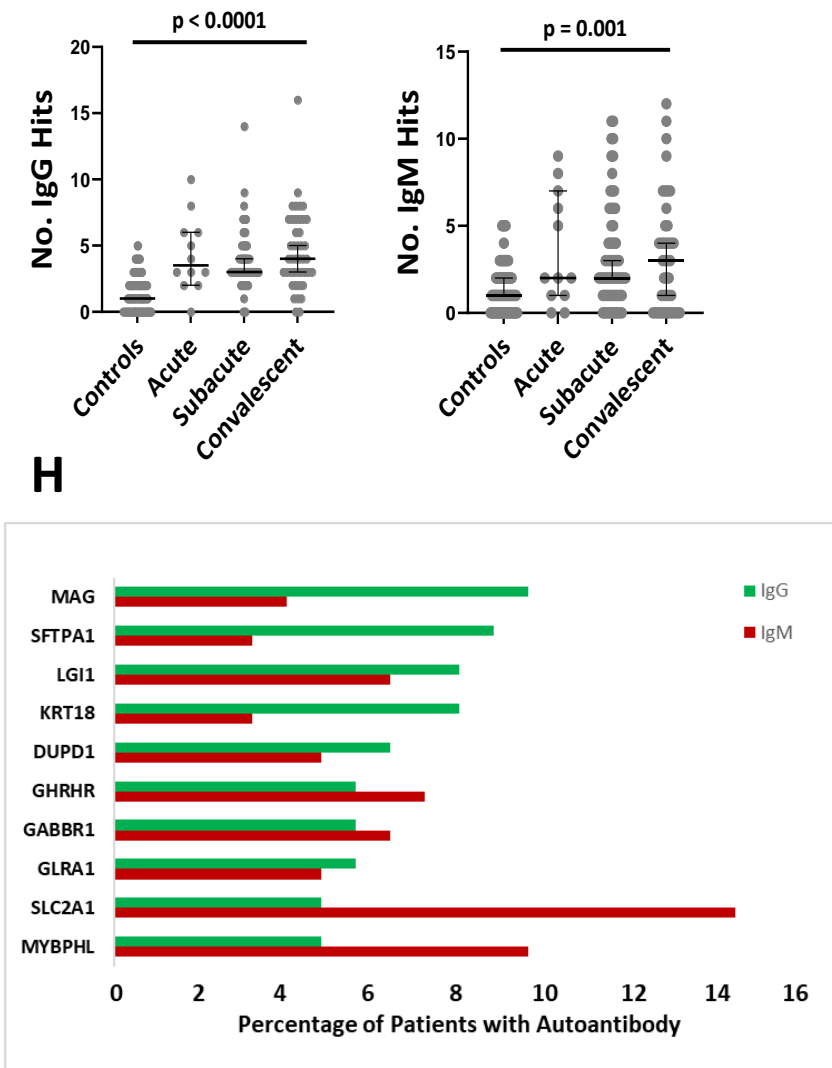

J

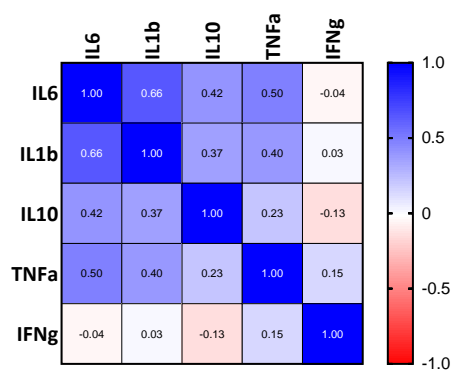

B

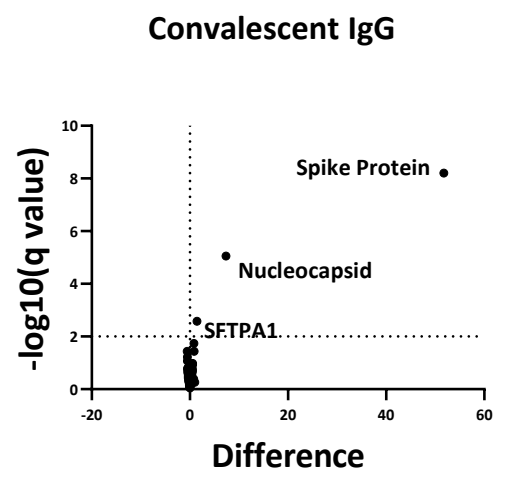

$\mathbf{F}$
C

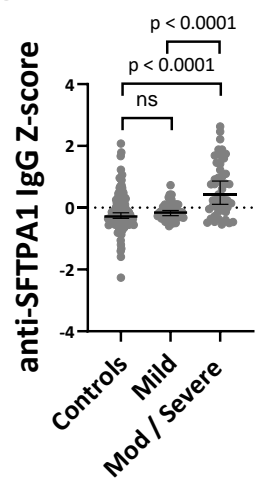

G
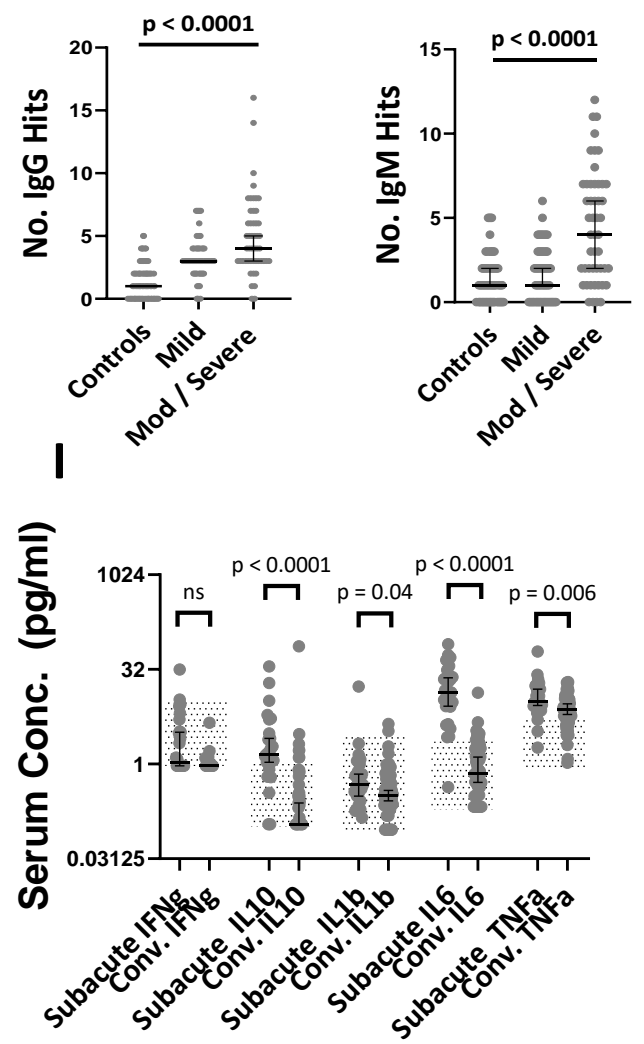

L

M
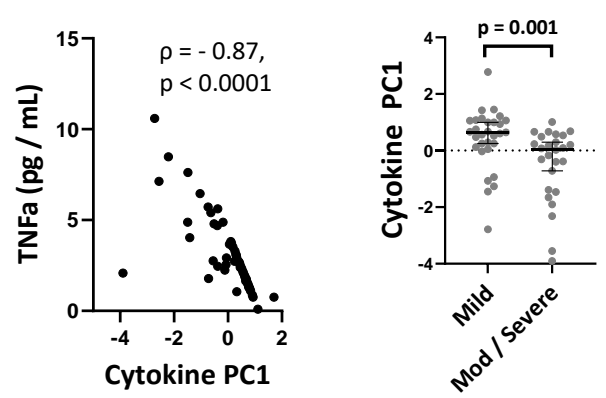
medRxiv preprint doi: https://doi.org/10.1101/2021.12.03.21266112; this version posted December 5, 2021. The copyright holder for this preprint (which was not certified by peer review) is the author/funder, who has granted medRxiv a license to display the preprint in perpetuity.

It is made available under a CC-BY-ND 4.0 International license

Figure 2. Autoantibody profiling in COVID-19. A\&B) Volcano plots of groupwise comparisons in autoantibody profiles between COVID-19 patients and controls C) Relationship between disease severity and anti-SFTPA1 IgG autoantibodies D\&E) Temporal profiles of IgG and IgM autoantibody responses F\&G) Effect of disease severity on number of IgG and IgM autoantibody "hits". H) Top ten most frequently detected autoantibodies across all samples. I) Comparison of cytokine profiles at the subacute and convalescent timepoints, with normal range shown by hatching. J) Correlation matrix between measured subacute cytokines $\mathbf{K}$ ) Loadings plot from principal component analysis demonstrating the contributions of proinflammatory cytokines to $\mathrm{PC} \mathbf{1} \mathrm{L}$ ) Comparison in subacute proinflammatory cytokine response between mild and moderate / severe disease. Volcano plots use multiple Mann-Whitney $U$ tests with a falsediscovery rate set to 1\%; Multiple group comparisons are by Kruskal-Wallis test with post-hoc Dunn's multiple comparison test; two-group unpaired comparisons are by Mann-Whitney $U$ test, correlation matrix is by Spearman's rank 
medRxiv preprint doi: https://doi.org/10.1101/2021.12.03.21266112; this version posted December 5, 2021. The copyright holder for this preprint (which was not certified by peer review) is the author/funder, who has granted medRxiv a license to display the preprint in It is made available under a CC-BY-ND 4.0 International license.

A

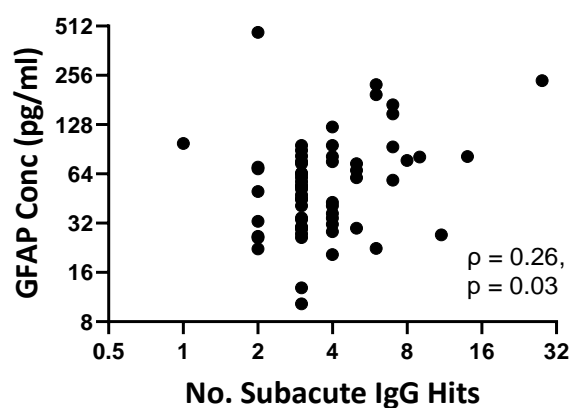

C

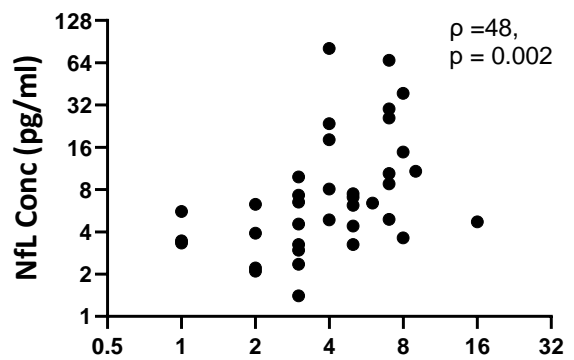

No. Convalescent IgG Hits
B

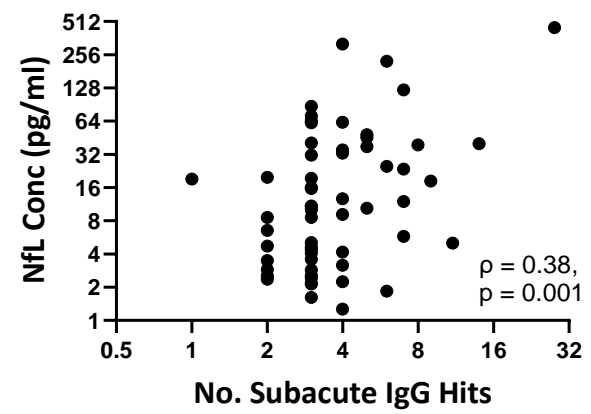

D

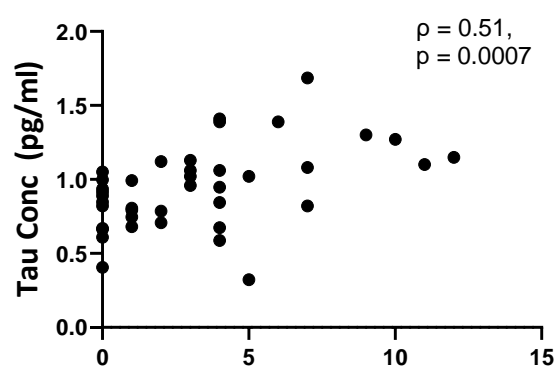

No. Convalescent IgM Hits

E

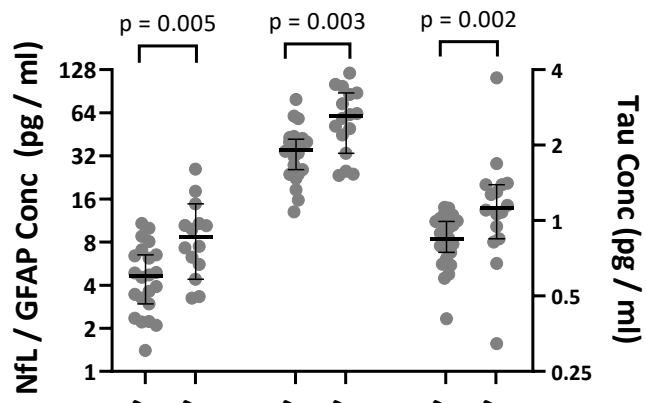


medRxiv preprint doi: https://doi.org/10.1101/2021.12.03.21266112; this version posted December 5, 2021. The copyright holder for this preprint (which was not certified by peer review) is the author/funder, who has granted medRxiv a license to display the preprint in perpetuity.

It is made available under a CC-BY-ND 4.0 International license .

Figure 3. Relationship between serum brain injury biomarkers and autoantibody profiles. A\&B) Correlation between number of IgG hits and serum GFAP and NfL concentrations at the subacute timepoint. C) Correlation between number of IgG hits and serum $\mathrm{NfL}$ concentrations at the convalescent timepoint. D) Correlation between number of IgM hits and serum total Tau concentrations at the convalescent timepoint. E) Comparison of convalescent serum brain injury biomarker concentrations between patients with high $\lg$ responses ( $\geq 3 \operatorname{lgM}$ hits $Z \geq 3$ ) versus those with low IgM responses ( $<3$ IgM hits $Z \geq 3$ ). Two-group unpaired comparisons are by Mann-Whitney $U$ test, correlations are by Spearman's rank

$\begin{array}{lccc} & \text { Acute }(\mathbf{n}=\mathbf{4 8}) & \text { Subacute }(\mathbf{n}=\mathbf{1 2 3}) & \text { Convalescent } \mathbf{n}=\mathbf{7 9}) \\ \text { GFAP HC } & 42.2[32.2-68.6] & 42.2[32.2-68.6] & 42.2[32.2-68.6] \\ \text { GFAP Mild } & 55.3[43.7-113] & 34.5[27.5-70.5] & 42.15[26.2-79.2] \\ \text { GFAP Mod } & 143.5[64.6-259] & 54.3[40.7-80.7] & 55.8[44.9-104.0] \\ \text { GFAP Sever } & 98.1[87.3-208.5] & 82.2[64-165.9] & 41.9[34.5-74.6] \\ \text { NfL HC } & 5.5[3.6-10.4] & 5.5[3.6-10.4] & 5.5[3.6-10.4] \\ \text { NfL Mild } & 8.2[2.6-15.9] & 4.2[2.8-9.1] & 4.8[3.0-10.0] \\ \text { NfL Mod } & 19.2[11.1-30.7] & 10.1[5.1-16.0] & 10.4[6.9-18.0] \\ \text { NfL Severe } & 30.6[14.3-81.3] & 45.6[30.8-98.7] & 10.8[7.4-19.4 \\ \text { Tau HC } & 0.72[0.60-1.04] & 0.72[0.60-1.04] & 0.72[0.60-1.04] \\ \text { Tau Mild } & 0.78[0.65-1.21] & 0.80[0.66-1.03] & 0.95[0.75-1.11] \\ \text { Tau Mod } & 0.74[0.49-1.10] & 0.39[0.18-0.73] & 0.90[0.71-1.27] \\ \text { Tau Severe } & 0.68[0.33-1.02] & 0.94[0.68-1.24] & 0.91[0.73-1.27]\end{array}$

Supplementary Table 1. Brain injury biomarker data. Values shown are median [IQR].

$H C=$ healthy controls $(n=59) ;$ Mild $(n=70)$, Mod (Moderate; $n=72)$, and Severe $(n=33)$ relates to severity of COVID-19. 
medRxiv preprint doi: https://doi.org/10.1101/2021.12.03.21266112; this version posted December 5, 2021. The copyright holder for this preprint (which was not certified by peer review) is the author/funder, who has granted medRxiv a license to display the preprint in It is made available under a CC-BY-ND 4.0 International license .

\begin{tabular}{|c|c|c|}
\hline Central Nervous System & Kidney & Lung \\
\hline $\begin{array}{l}\text { ANXA4 APP BSG CDH13 } \\
\text { CDR2 CHRNA9 COL4A3BP } \\
\text { DCN DPYSL5 DRD2 ELAVL4 } \\
\text { GABBR1 GABRA1 GABRB3 } \\
\text { GAD1 GAD2 GFAP GLRA1 }\end{array}$ & $\begin{array}{c}\text { AGTR1 COL4a3 GSTT1 MPO } \\
\text { NPHS2 PLA2R PRTN3 } \\
\text { SLC22A12 TMEM174 UMOD } \\
\text { VIM }\end{array}$ & $\begin{array}{c}\text { AGER COL1A1 COL1A2 } \\
\text { COL5A2 SCGB1A1 SCGB3A2 } \\
\text { SFTPA1 SFTPA2 SFTPC } \\
\text { TUBA1B }\end{array}$ \\
\hline $\begin{array}{l}\text { GRIA3 GRIA4 GRIN1 GRIN2A } \\
\text { GRIN3A GRIN3B GRINA } \\
\text { GRM1 GRM2 GRM3 GRM4 } \\
\text { GRM7 GRM8 KCNJ10 LGI1 } \\
\text { MAG MAPT MBP MOG NEFL }\end{array}$ & $\begin{array}{c}\text { Muscle } \\
\text { ACTA1 ANKRD23 CHRNA10 } \\
\text { DUPD1 HARS IDI2 PPP1R27 } \\
\text { TPM1 TTN UCP3 }\end{array}$ & $\begin{array}{c}\text { Heart } \\
\text { CHRM2 EDNRA LRRC10 } \\
\text { MYBPHL MYL4 MYL7 NPPA } \\
\text { NPPB TNNI3 TNNT2 }\end{array}$ \\
\hline PNMA2 S100B SNCA SSB & \multirow{4}{*}{$\begin{array}{c}\text { HLA } \\
\text { CD74 HLA-A HLA-B HLA-C } \\
\text { HLA-DMA HLA-DMB HLA- } \\
\text { DOA HLA-DOB HLA-DPA1 } \\
\text { HLA-DPB1 HLA-DQA1 HLA- } \\
\text { DQB1 HLA-DQB2 HLA-DRA } \\
\text { HLA-DRB1 HLA-DRB3 HLA- } \\
\text { DRB4 HLA-DRB5 HLA-E HLA- } \\
\text { F HLA-G }\end{array}$} & Endocrine \\
\hline $\begin{array}{l}\text { TPH1 TROVE2 TUBB3 } \\
\text { UCHL1 ZIC4 }\end{array}$ & & $\begin{array}{c}\text { FSHB GHRHR GNRHR POMC } \\
\text { PRL TSHB TPO TSHR }\end{array}$ \\
\hline $\begin{array}{c}\text { Blood Brain Barrier } \\
\text { CLDN5 LAMC2 SELE SLC2A1 } \\
\text { TJP1 }\end{array}$ & & $\begin{array}{c}\text { Coagulation } \\
\text { ADAMTS13 ANXA5 APOH F2 } \\
\text { F7 F8 F9 FGB PROC PROS1 }\end{array}$ \\
\hline Ubiquitous & & COVID-19 \\
\hline $\begin{array}{c}\text { ACE CDH1 CEACAM1 } \\
\text { CEACAM5 CENPB CENPH } \\
\text { DBT DDC DLAT IFNA1 KRT18 } \\
\text { NUP210 TGM2 ZNF397 }\end{array}$ & & $\begin{array}{l}\text { Spike protein } \\
\text { Nucleocapsid }\end{array}$ \\
\hline
\end{tabular}

Supplementary Figure 1. Protein microarray antigen composition 

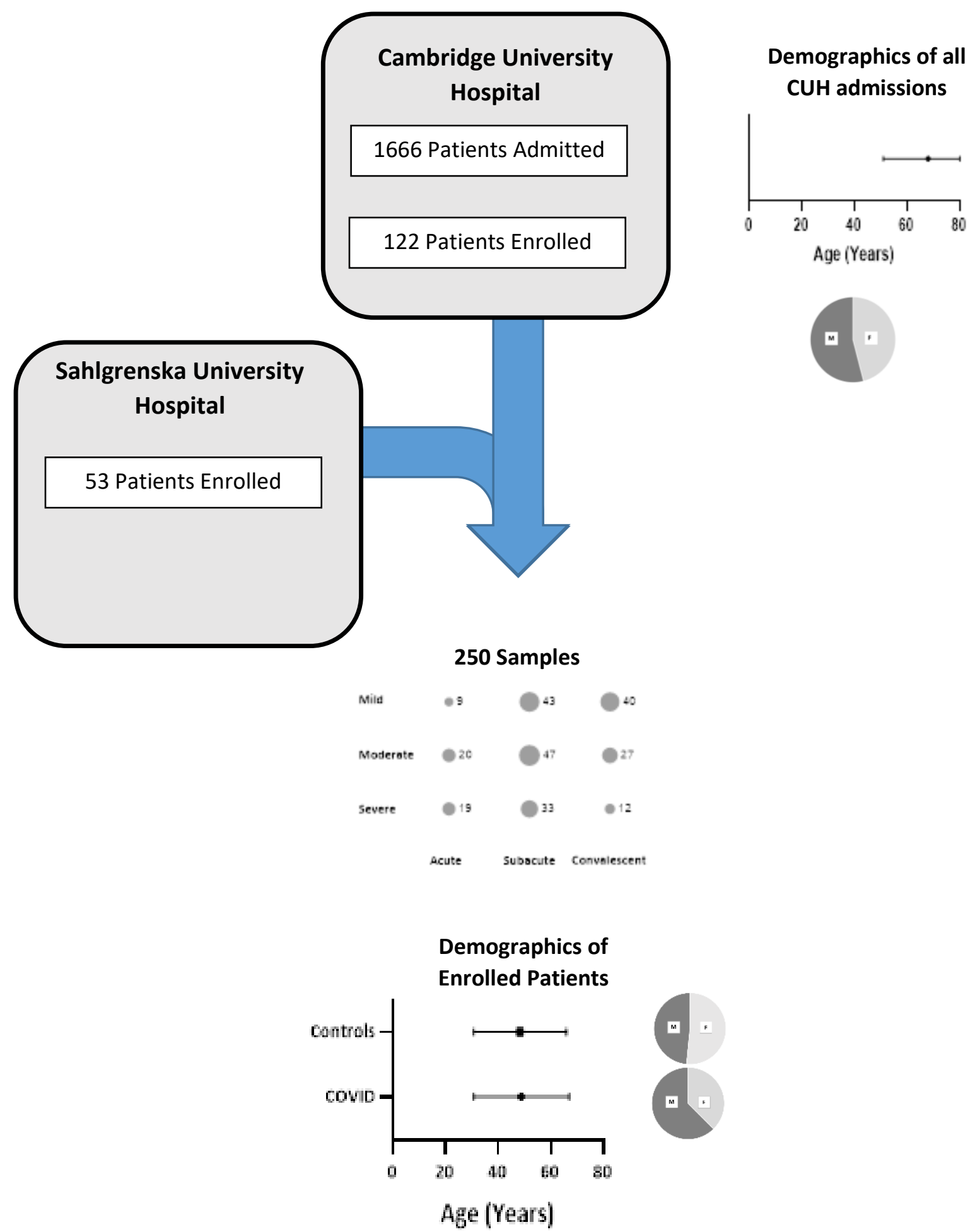

Supplementary Figure 2. Demographic and sample details of patients and controls for both biomarker quantification and autoantibody profiling experiments. 
medRxiv preprint doi: https://doi.org/10.1101/2021.12.03.21266112; this version posted December 5, 2021. The copyright holder for this preprint (which was not certified by peer review) is the author/funder, who has granted medRxiv a license to display the preprint in

It is made available under a CC-BY-ND 4.0 International license .

A

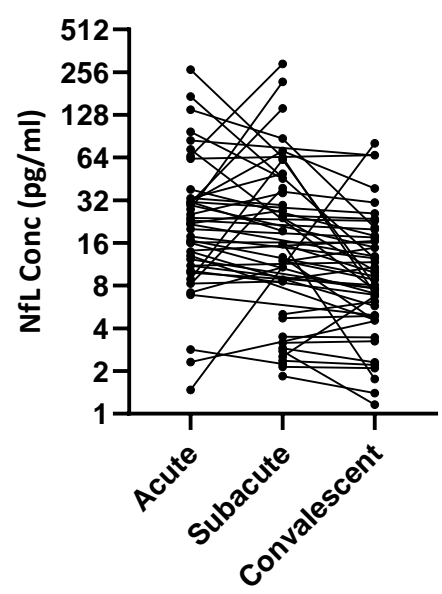

B
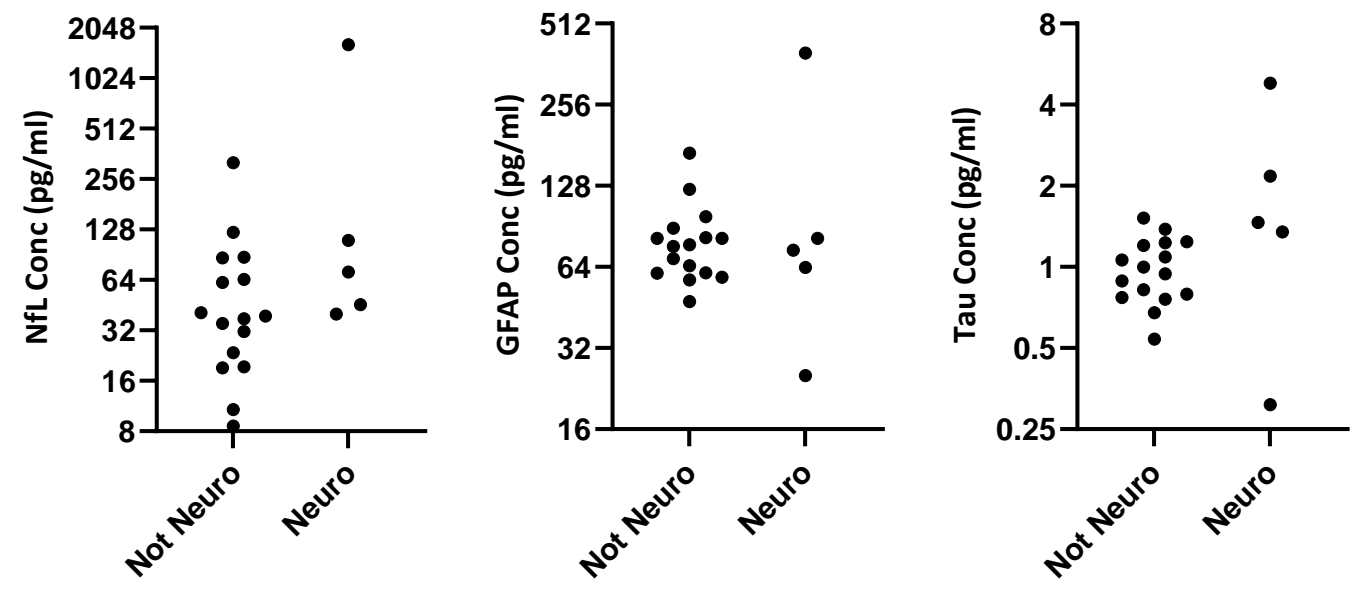

Supplemental Figure 3. A) Spaghetti plot displaying temporal profiles of $\mathrm{NfL}$ in patients who contributed longitudinal samples B) Comparison of brain injury biomarkers between those patients with severe COIVD-19 who developed syndromic neurological diagnoses (mononeuritis multiplex $n=$ 3 , opsoclonus myoclonus $n=1$, peripheral neuropathy with concurrent encephalopathy $n=1$ ) versus those who did not. 
medRxiv preprint doi: https://doi.org/10.1101/2021.12.03.21266112; this version posted December 5, 2021. The copyright holder for this preprint (which was not certified by peer review) is the author/funder, who has granted medRxiv a license to display the preprint in

perpetuity.
It is made available under a CC-BY-ND 4.0 International license.

Supplementary Table 2 Frequency of Positive Autoantibody hits

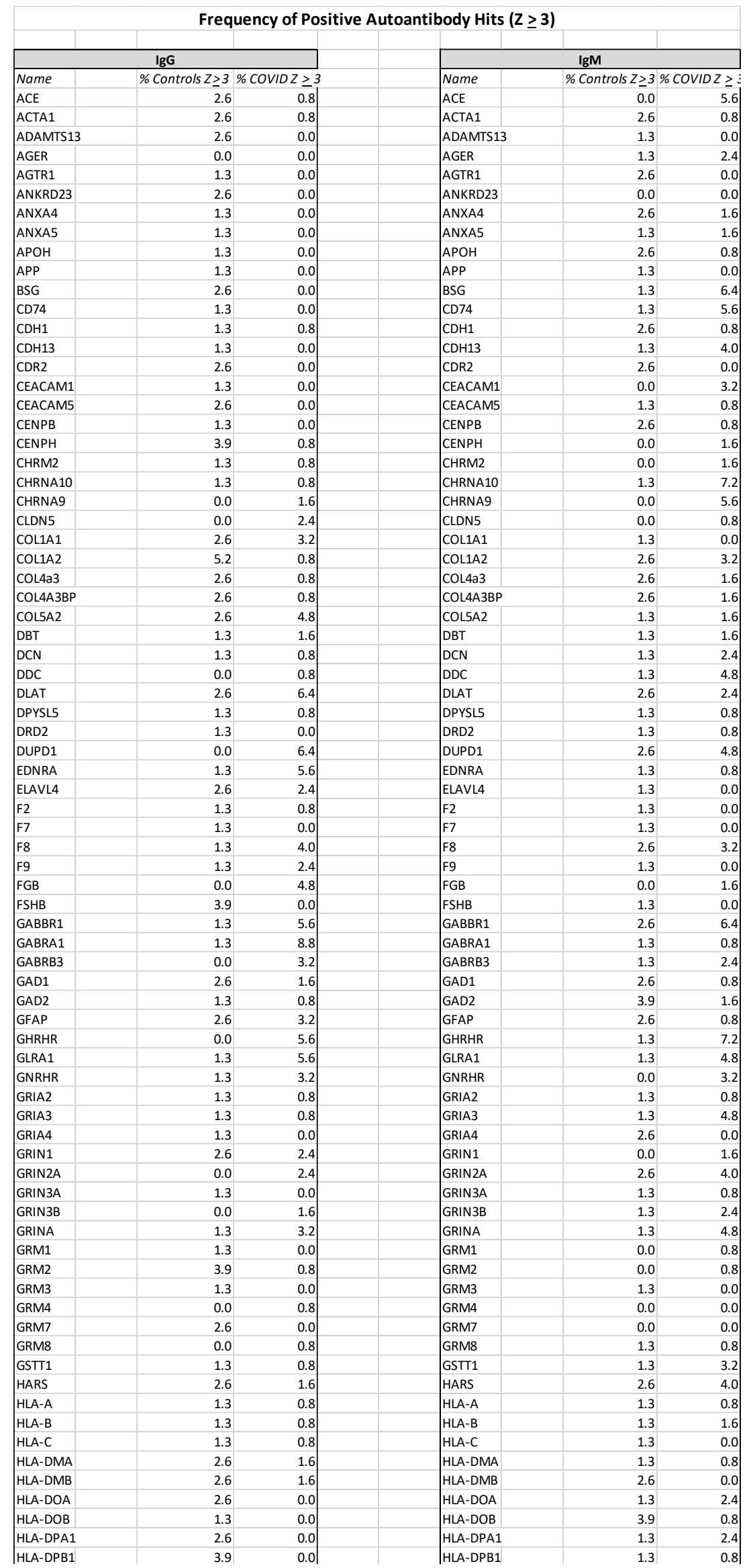


medRxiv preprint doi: https://doi.org/10.1101/2021.12.03.21266112; this version posted December 5, 2021. The copyright holder for this preprint (which was not certified by peer review) is the author/funder, who has granted medRxiv a license to display the preprint in

perpetuity.
It is made available under a CC-BY-ND 4.0 International license .

\begin{tabular}{|c|c|c|c|c|c|}
\hline HLA-DQA1 & 2.6 & 0.0 & HLA-DQA1 & 1.3 & 0.8 \\
\hline HLA-DQB1 & 5.2 & 0.0 & HLA-DQB1 & 0.0 & 0.8 \\
\hline HLA-DQB2 & 1.3 & 0.0 & HLA-DQB2 & 1.3 & 0.0 \\
\hline HLA-DRA & 0.0 & 0.0 & HLA-DRA & 0.0 & 5.6 \\
\hline HLA-DRB1 & 1.3 & 1.6 & HLA-DRB1 & 0.0 & 7.2 \\
\hline HLA-DRB3 & 2.6 & 0.0 & HLA-DRB3 & 0.0 & 0.8 \\
\hline HLA-DRB4 & 3.9 & 2.4 & HLA-DRB4 & 0.0 & 6.4 \\
\hline HLA-DRB5 & 2.6 & 0.0 & HLA-DRB5 & 1.3 & 0.0 \\
\hline HLA-E & 0.0 & 0.0 & HLA-E & 0.0 & 0.8 \\
\hline HLA-F & 1.3 & 0.8 & HLA-F & 0.0 & 0.0 \\
\hline HLA-G & 1.3 & 1.6 & HLA-G & 1.3 & 2.4 \\
\hline IDI2 & 2.6 & 0.0 & IDI2 & 0.0 & 1.6 \\
\hline IFNA1 & 1.3 & 0.8 & IFNA1 & 1.3 & 0.0 \\
\hline KCNJ10 & 2.6 & 4.0 & KCNJ10 & 1.3 & 0.0 \\
\hline KRT18 & 1.3 & 8.0 & KRT18 & 1.3 & 3.2 \\
\hline LAMC2 & 1.3 & 0.8 & LAMC2 & 1.3 & 3.2 \\
\hline LGI1 & 1.3 & 8.0 & LGI1 & 1.3 & 6.4 \\
\hline LRRC10 & 2.6 & 0.0 & LRRC10 & 1.3 & 0.0 \\
\hline MAG & 0.0 & 9.6 & MAG & 1.3 & 4.0 \\
\hline MAPT & 2.6 & 0.0 & MAPT & 1.3 & 0.8 \\
\hline MBP & 1.3 & 0.0 & MBP & 1.3 & 2.4 \\
\hline MOG & 1.3 & 0.0 & MOG & 1.3 & 0.8 \\
\hline MPO & 2.6 & 0.8 & MPO & 1.3 & 6.4 \\
\hline MYBPHL & 0.0 & 4.8 & MYBPHL & 1.3 & 9.6 \\
\hline MYL4 & 1.3 & 0.0 & MYL4 & 1.3 & 1.6 \\
\hline MYL7 & 1.3 & 0.0 & MYL7 & 0.0 & 0.0 \\
\hline NEFL & 2.6 & 2.4 & NEFL & 0.0 & 5.6 \\
\hline NOVA1 & 2.6 & 0.0 & NOVA1 & 2.6 & 5.6 \\
\hline NPHS2 & 2.6 & 3.2 & NPHS2 & 2.6 & 2.4 \\
\hline NPPA & 1.3 & 0.0 & NPPA & 3.9 & 0.0 \\
\hline NPPB & 2.6 & 4.0 & NPPB & 0.0 & 2.4 \\
\hline Nucleocap & 1.3 & 59.2 & Nucleocap & 3.9 & 0.0 \\
\hline NUP210 & 2.6 & 0.8 & NUP210 & 2.6 & 1.6 \\
\hline OMG & 1.3 & 0.0 & OMG & 0.0 & 0.0 \\
\hline PLA2R1 & 1.3 & 4.0 & PLA2R1 & 1.3 & 0.0 \\
\hline PNMA1 & 1.3 & 0.0 & PNMA1 & 2.6 & 3.2 \\
\hline PNMA2 & 2.6 & 2.4 & PNMA2 & 1.3 & 0.0 \\
\hline POMC & 1.3 & 0.0 & POMC & 1.3 & 0.0 \\
\hline PPP1R27 & 2.6 & 0.0 & PPP1R27 & 1.3 & 2.4 \\
\hline PRL & 2.6 & 0.0 & PRL & 1.3 & 0.8 \\
\hline PROC & 1.3 & 2.4 & PROC & 1.3 & 0.8 \\
\hline PROS1 & 1.3 & 0.0 & PROS1 & 2.6 & 0.8 \\
\hline PRTN3 & 2.6 & 0.8 & PRTN3 & 2.6 & 0.8 \\
\hline Rhodamin & 1.3 & 0.8 & Rhodamin & 1.3 & 0.0 \\
\hline S100B & 1.3 & 0.0 & S100B & 1.3 & 0.0 \\
\hline SCGB1A1 & 1.3 & 0.0 & SCGB1A1 & 1.3 & 0.0 \\
\hline SCGB3A2 & 1.3 & 0.0 & SCGB3A2 & 1.3 & 2.4 \\
\hline SELE & 1.3 & 1.6 & SELE & 1.3 & 4.0 \\
\hline SFTPA1 & 0.0 & 8.8 & SFTPA1 & 1.3 & 3.2 \\
\hline SFTPA2 & 1.3 & 0.8 & SFTPA2 & 2.6 & 0.0 \\
\hline SFTPC & 3.9 & 1.6 & SFTPC & 0.0 & 4.0 \\
\hline SLC22A12 & 2.6 & 0.0 & SLC22A12 & 0.0 & 0.0 \\
\hline SLC2A1 & 0.0 & 4.8 & SLC2A1 & 1.3 & 14.4 \\
\hline SNCA & 0.0 & 0.0 & SNCA & 1.3 & 0.0 \\
\hline Spike prot & 1.3 & 80.0 & Spike prot & 1.3 & 36.0 \\
\hline SSB & 1.3 & 3.2 & SSB & 2.6 & 6.4 \\
\hline TGM2 & 1.3 & 0.0 & TGM2 & 2.6 & 0.8 \\
\hline TJP1 & 1.3 & 0.0 & TJP1 & 1.3 & 1.6 \\
\hline TMEM174 & 1.3 & 2.4 & TMEM174 & 0.0 & 5.6 \\
\hline TNNI3 & 2.6 & 2.4 & TNNI3 & 1.3 & 3.2 \\
\hline TNNT2 & 2.6 & 0.8 & TNNT2 & 1.3 & 0.8 \\
\hline TPH1 & 1.3 & 1.6 & TPH1 & 1.3 & 3.2 \\
\hline TPM1 & 3.9 & 0.0 & TPM1 & 1.3 & 0.8 \\
\hline TPO & 1.3 & 1.6 & TPO & 1.3 & 1.6 \\
\hline TROVE2 & 2.6 & 4.8 & TROVE2 & 1.3 & 0.8 \\
\hline TSHB & 1.3 & 0.0 & TSHB & 1.3 & 0.0 \\
\hline TSHR & 1.3 & 2.4 & TSHR & 0.0 & 0.8 \\
\hline TTN & 1.3 & 0.0 & TTN & 2.6 & 2.4 \\
\hline TUBA1B & 2.6 & 0.0 & TUBA1B & 1.3 & 0.0 \\
\hline TUBB3 & 1.3 & 0.0 & TUBB3 & 1.3 & 3.2 \\
\hline UCHL1 & 1.3 & 0.0 & UCHL1 & 1.3 & 2.4 \\
\hline UCP3 & 1.3 & 1.6 & UCP3 & 2.6 & 0.0 \\
\hline UMOD & 1.3 & 4.0 & UMOD & 3.9 & 1.6 \\
\hline VIM & 2.6 & 0.0 & VIM & 2.6 & 1.6 \\
\hline ZIC4 & 1.3 & 0.0 & ZIC4 & 0.0 & 0.8 \\
\hline ZNF397 & 2.6 & 1.6 & ZNF397 & 1.3 & 0.0 \\
\hline
\end{tabular}

